\title{
Social Mood and Ethnic Tension: The Case of the Former USSR
}

\author{
Sergei Kharchenko
}

\section{Abstract}

The author analyzes the phenomenon of social mood and its impact on the intensification of ethnic tensions. According to him, the mobility and the variability of the social mood can be expressed through the display of its intensity, which is especially pronounced in the deepest shifts occurring in the bosom of ethnic self-consciousness during the times of social turmoil. The article makes it evident that many international and interethnic tragedies could be avoided, if the authorities reacted to the fluctuations of social mood of the people on time. The sociological studies of ethnic conflicts and tensions on the territory oftheformer USSRafterits disintegration serve as an illustration material for his theory.

\section{Precis}

L'auteur analyse Ie phenomene de la morosite sociale et son impact sur 1'intensification des tensions ethniques. Selon lui, la mobilite et la variabilite de la morosite sociale tend ii s' exprimerpar la manifestation de son intensite, laquelle est particulierement prononcee lors des mouvements abrupts et profonds qui se produisent au sein de la conscience de soi ethnique dans les phases de troubles sociaux. L' article montre clairement que de nombreuses tragedies internationales et inter-ethniques pourraient are evitees si les autorites savaient reagir adequatement et au bon moment ii la fluctuation de la morosite sociale. L' etude sociologique des con flits et tensions ethniques sur Ie territoire de I' ex-URSS apres sa desintegration sert d'illustration materielle de la theorie de I' auteur.

Sergei Kharchenko, Ph.D. in sociology, is the Professor of Kostanai State University, Kostanai, Kazakhstan. He has devoted the last nine years of his research to the study of the social mood.

This article was translated from the Russian by Victoria Benifand.

\section{Introduction}

The mobility and the variability of the social mood can be expressed through the display of its intensity: strong, moderate, and weak. This display can be very evident and rough, when it springs out of the deepest emotions and indispensable and immediate aspirations of the people to realize in their acts the highest goalstrong conviction in the correctness of a given frame of mind or restrained and broken values that are allowed to resurface. In its other extreme, the social mood can practically not display itself, being completely identified with the existing public consciousness, in which there are not enough dominant trends and orientations that could induce any form of active expression. Such passivity of the people allows their mood to be characterized as weak in intensity.

\section{Stages of Ripening of the Intensity of the Social Mood}

The various degrees of intensity of social mood are especially visible in the deepest shifts occurring in the bosom of national self-consciousness during the times of radical social changes. This phenomenon can be characterized by a complex scale of the most diverse feelings and frames of mind-from the delight accompanying the resurgence of national identity on the first plane, to the disappointment and apathy, when the expected positive shifts did not occur.

In the past, the existence of the USSR instilled trust in the souls of many millions of people and kept their social mood at a constant, stable level. There was the sense of patriotism in their relation to the country. In such conditions, people were proud in their country for its power and leadership. At the same time, the ethnosocial development in the USSR was rather murky. The attempts of the authorities to hide the con- tradictions that were arising again (though they had new basis) eventually led to the powerful outbreak of the national selfconsciousness which contributed to the destabilization and the collapse of the USSR.

However, since World War II, the struggle of the main ethnic groups for dominance in their republics commenced and increased, and sometimes led to hidden discrimination against the representatives of other nations. Such social processes contributed to latent destructive action against the unity of the whole country. Thus, the migration processes, mainly the outflow of Russian population from the republics, began as early as at the end of the 1970s, when, for the first time, statistical information revealed this trend, which started in Georgia. ${ }^{1}$ However, despite this situation, nobody became interested in the social status and social mood of the people and even bothered asking questions, why Russians leave this God -blessed, rich, fertile and seemingly hospitable territory? Seeds of mistrust were planted in the minds of the people who displayed distrust for each other as well as suspicions and doubt of the officially proclaimed values.

The hopes of the representatives of various nations at the first stage of perestroika were directed towards the revival of national cultures-their customs, tradition, and the renewal of interest in the native languages. According to an allSoviet research of historical consciousness, conducted in 1990 and directed by Dr. V. 1. Merkushin, the aspiration to learn the historical roots of the country and its people was expressed by 28 percent of the respondents of this study. It placed only behind the aspirations to know the truth about the past (41\%) and the desire to expand .one's views and outlooks (30\%). About the same number of people (27\%) said, that they are interested in the "life, customs, traditions of the peoples, and their oral 
national creativity."2 The social mood in this period could be characterized as joyfully anticipating, active, and constructive.

To a certain extent, the results of this research summed up the first stage in the development and the renewal of the national self-consciousness in the USSR. The respect for the native languages and the ethnic cultures, that gained momentum during the period of perestroika, contributed to the enrichment of the nationalidentity. Practically all people of the former USSR displayed a deep interest in their ancestors, their customs and language, since they were allowed to do so. Consequently, the social mood became more optimistic. It was accompanied by the expectations of a considerable improvement of the wellbeing of the people in the near future. The social mood received an increasingly ethnosocial colouring, though its intensity had unilateral, emotional, impulsive character.

Then, the process of reorganization of the whole country linked the social mood of the people to high expectations of gaining the economic sovereignty and even the formation of national states. Many politicians of nationalistic viewpoints in Soviet republics thought that it was just enough to be liberated from the Soviet dictatorship in order to bless their populations with a life better, than the one they experienced within the framework of the USSR with its dicta torial form of government.

There was also another, higher level of fire in the nationalistic ambitions, at least among the intellectuals, who passionately preached ideas of national economic sovereignty. The rigid centralization so characteristic for the USSR that limited the rights and opportunities of the republics was fairly rejected. Thus, the local propaganda stressed that each of the republics could be much better off as an independent state. There were the numerous articles in all allied republics, which tried to prove that each republic was using much less than it produced. Where did the surplus go? However not stated openly, itwas assumed that the surplus went to Russia. Moreover, the calcula- tions were done using the existing prices of that time in the USSR (instead of the world prices).

In addition, at the same time, people mulled over the idea whether" centre of the empire" was exploiting and abusing them. Gradually the Russian population was viewed as the representatives of the" centre of the empire." The ideas of national economic sovereignty, present mainly in theories and accounts of intellectuals, entered the minds and penetrated deep into the consciousness of the masses. At first, these ideas pronounced themselves in the public desire to set down economic borders not only between republics, but also between the their inhabitants based on nationality. It can seem surprising, but social expectations and social hopes only strengthened the presentiment of economic well-being and material prosperity. In these conditions, the social mood was still far more constructive than destructive. The mood was elevated, joyfully patient, positive and healthy emotionally. However, exactly during this period, the mood of the people, social groups, and even nationalities began to absorb negative features of consciousness and behaviour, such as suspicion towards other ethnic groups, feeling of deprivation, and strong beliefs in the superiority of one nation and republic in the level of economic development and opportunities for achieving higher standard of livingifonlytheycould workindependently.

But the intensity of social mood reached its apogee during the radical transformations in the political sphere in the republics, i.e. the receiving of a political independence, which in the end resulted in the break-up of the USSR and the formation of the new states. The brakes on raging nationalism and political ambitions were finally removed. National affairs have moved to the third stage-a stage of building sovereignty. The logic ofleaders of nationalistic orientation at that time was very transparent-national, cultural and economic questions could be fruitfully addressed only after the victory of their political platform. The public con- sciousness in these conditions became an object of active manipulation, and the social mood $\backslash$; as associated with national and ethnic interests only.

In 1991, for example, the official authorities of the Ukraine jumped to the conclusion that people voted for the break-up of Russia, for burial of the Unitarian state, after the overwhelming majority of the population positively answered to a question given in the autumn 1991: "Do you want to live in a free and democratic country?" What was the basis for such conclusion and the relevance to the opinion of the people of Ukraine, who in the spring that year supported the idea of preservation of the USSR? After all, who does not want to live in a free and democratic country? Thus, how such questions and answers should be interpreted becomes a critical issue, especially during great social upheavals.

Such tricky and misleading referenda, as well as conclusions drawn from them, formed the ground not only for the nationalistic ambitions of the local political leaders, but also provoked a part of the population to display the worst human qualities-open prejudice towards other ethnic groups. These conditions implanted in the minds of the population the idea of revisiting historical claims, debts, and insults (apparent and imagined) that were often not only a century, but also a thousand years old. This simultaneous, "teleological" and spontaneous disruption of the former structure of the relations between various ethnic groups resulted in the growth of social and sociopsychological discomfort among the people.

The people became also more disturbed by the rising international conflicts. Even in ethnically homogenous regions, there might be a very high level of anxiety. Experts have named 36 (some up to 150) areas in Russia (and outside Russia), in which the international conflicts are close to erupting. Economic, and more often political, claims are often kept in disguise hidden behind legitimate national aspirations and the debates on national culture, sovereignty and language. National interests 
often serve as the screen for political claims and ambitions, lust for power and authority and special privileges.

Many international tragedies could be avoided, if authorities had reacted to mass social mood in a timely fashion. For example, in the 1960s and 1970s, in the Kazakhstan republic, the idea of the creation of an independent area for Germans, who were violently deported in 1940s from the Volga region, became an issue. However, this idea was not supported by the official authorities of Kazakhstan. Consequently, the republic has lost (and continues to lose due to emigration) tens of thousands of efficient, disciplined professionals. A barrier of political alienation between Germans and Kazakhs has been created and has caused instability in industrial spheres. The data of the State Committee of republic says that "nonnative" population makes up 76 percent of those employed in the industrial sector. This percentage is even higher in coal mining. ${ }^{3}$

Analyzing the condition of the mood in connection with interethnic and national mutual relations, one is compelled to draw a disappointing conclusion. As for at the moment, the international level of intensity remains high in the former republics of USSR. Answers given by approximately half of the questioned representatives of various groups testify to the tense relations between the peoples of the former USSR, and one quarter of them even allows for an opportunity of occurrence of the conflicts on the nationallevel. ${ }^{4}$

\section{Levels of Intensity}

Empirical research and analysis of the conflicts show that there are three levels of intensity in interethnic relations that affect a degree of intensity of social mood of specific ethnic groups, nations.

The first one, ethnic limitations (i.e., unwillingness to have contacts with those who do not subscribe to one's national or ethnic ethos), is the most common. It exhibits itself in increasing support for mono-ethic families (there is the reduction in the number of mixed marriages), in preference to work in "mono-national" collectives, and in the monopolization of the establishment of all levels by the representatives of one ethnic group.s

Practically all of the peoples, especially those who in ethnic states or ethnic and territorial autonomy, suffer from this illness, which is often a starting point for the formation of selfish national mood, and consequently the destruction of international consent. During the initial stage of creation of nationalistic and chauvinist views and intentions, the social mood as a whole is peaceful and favourable towards the others, and it does not provide the framework for individual negative episodes of ethnic conflict, which at this stage do not are not given a special meaning.,A more complex situation has arisen during the birth of the new independent states in the territory of the former USSR, after new structures of official and informal mutual relations of the people of various ethnicity started to form. Russians have suffered the most in this new political reality. In the majority of the newly independent states, they have become an ethnic minority, discriminated against by various farfetched restrictions and regulations.

The second level of interethnic tension is ethnic selfishness (keeping the privileges by one ethnic group at the expense of the others). It is a step not only towards creating tensions in the relationships between people, but also towards a high degree of intensity of the social mood of the people of different ethnic backgrounds,

As sociological surveys show, that up to $30-40$ percent of the native people of the republics consider as naturalhaving more privileges than other ethnic groups living there. However, the employment of Russians is still greater in industry and, partly, in science, public health services, and education. At the same time, in all other spheres and branches of the state and economy, the percent of Russians is lower than the percent of the dominant groups. In Baltic states, for example, de facto there are even strong restrictions on the usage of natural resources on the basis of ethnic background. Shares are withheld from
Russian shareholders and provided only to the native people. ${ }^{6}$

In Dagestan, ethnic selfishness is displayed in tensions between Laks and Koumics over of the Koumics' land, while, Nogais want a unification of all the Nogai territories, divided some time ago between Dagestan, Stavropol Territory, and Chechnya. ${ }^{7}$

In these conditions the social mood becomes infected with the virus of suspicion and mistrust; expectation of negative consequences and lose of stability are on the rise. Thus, under certain circumstances, social tensions on an interpersonal level as well as on a mass scale may erupt.

Ethnic selfishness can pass into a third a stage-ethnophobia, characterized by a direct and irreconcilable hostility towards to others. The violent displays of ethnophobia could be observed in Armenian-Azeri, GeorgianAbchazian conflicts, and also in Osetin-Ingush conflict, when even on an interpersonal level the hate, lack of tolerance, and accusation of each other continue up to day. Also separate regions that belong to Cossacks and those in Northern Caucasus are on the verge of open conflicts between various social and ethnic groups.

The explosive power of this phenomenon lays in a sphere of emotions subjected to ill-conceived suggestions and ideology. Domestic chauvinism-a phenomenon the function of which is to mobilize irrational emotions, is the powerful source of irritation, indignation, and hate. The existing prejudices and biases can serve as a strong motive for not only amoral, but also illegal, and deliberate actions against people who do not share common ethos.

In any society there are followers of ethos, which is the subject or object of aggressive nationalism, and even chauvinism, or both. In addition, domestic chauvinism appeals to and is strengthen by the national pride, illdefined sense of honour, presence of deformed judgements, false estimations, and false facts in people's consciousness. The phenomenon of domestic chauvinism as the category of real mood and social action does not 
have any organic universal properties inherent to it, neither certain psychological or physiological type with a special set of peculiarities, which would differ from all other people. The carrier of the phenomenon of aggressive nationalism and chauvinism can be persons from any social layer, independent of their profession, social status and intelligence. The infinite number of variations possible circumstances and events that can provoke this kind of attitude and behaviour do not leave much room for hope that some types of people or social groups are safe from a "backfiring" reaction.

Thus, it has to be emphasized again tha $t$ the most dangerous form of ethnic phobia is domestic chauvinism, which poisons the social mood of all parties participating in the conflict.

\section{Deformed Intensity}

For each person to compare one's nation to other nations and other people is a normal, and healthy process, as long as the understanding of the differences does lead to the feelings of superiority and a belief in exceptional character of one's nation or ethnic group.

The aspiration to superiority also appears when the person's rights are restrained, as well as when the opportunity to display self and build personal well-being is denied. Such a person searches for economic, political, and other reasons of his/her predicament. However, the answer is often found in the national injustice towards particular individuals as well as representatives of certain ethnic groups or nations. Then the exp lanation of all failures, miscalculations, errors, and falls becomes extremely simple-the other ethnic groups are guilty of everything.

When people of other ethnic groups in search of superiority offend a person, he or she no longer looks exclusively into personal experience. Thus the danger of deformed national consciousness arises. After being exposed to "facts" and "figures" provided by nationalistic propaganda, such a person begins to link his /her experience with those of other representatives of his /her people. In such case, personal insults are added to those insults and historical injustices suffered by one's ethnic group ornation. Unpublished sociological research conducted between 1992 and 1997 indicates that from fifteen to thirty percent of the respondents reflect this mode rof thinking.

Domestic chauvinism certainly has some objective basis. During the period of Soviet rules, many miscalculations, errors, and bad decisions were made. Even the internment of the large number of people took place. Severe scars have been left on the historical memory of the people. Therefore, instead of promoting the search for historical justice, the past often serves as the excuse for revenge in form of the infringement of the rights and the freedom of other people.

Another reason for the occurrence of domestic chauvinism is the fact that in these turbulent times, many people have lost social and professional identity. Collective labour has been devalued. Also, the identification of oneself as a Soviet citizen or person has been rejected by the majority of people and remained only as an unpleasant memory. However, people cannot live without identifying themselves with their environment. In the conditions of disorder, the idea of national belonging became attractive for many people and filled the existing identification vacuum. Already in 1990, according to the data of an all-Union research, most of the respondents ,62 percent, felt pride for their own people and nation, and 30 percent for collective labour, while 38 percent for their city or village. Due to the growing disorder in the country, the tendency to identify with one's nation or ethnic group has increased even more and has become, in opinion of many sociologists, the leading for of social identification. ${ }^{8}$ While considering this phenomenon and its role in the expression of the social mood, it is necessary to note that no single people or nation was free (and in foreseeable future will not be free) from domestic chauvinism. The dislike or even hate towards representatives of other peoples is displayed either openly and directly, or in a hidden and more passive way.
The most elementary form of chauvinism is represented by jokes about people of other ethnic backgrounds. These distortions of reality are fed by prejudices and negative stereotypes, from which no people are free. However, they are often the nuclei of domestic chauvinism, once they start to serve as the justification for the discriminatory policy and actions against other nations and ethnic groups.

Amore serious and deep harbinger of domestic chauvinism is the aspiration or tendency to become isolated inhomogeneous ethnic environment in work, sociallife,leisure, and daily life. However, the significant majority of the people in the former USSR (it is shown by the research done in the sixties and seventies) seemed to be free of such prejudices, and were even proud of the fact that they worked with colleagues from other ethnic groups, and had friends among them as well as sharing residence with the representatives of various ethnicities.

There are also people (and now this proportion has increased a little and makes up about $10 \%$ ), who are convinced in the utility of mono-cultural collectives and mono-cultural friendship and oppose mixed marriages. What about many intellectuals, who pretend to be open minded and in theory accept mixed marriages, but object to their children marrying someone of different ethnic, national or racial origin? Such flaw in public consciousness and its active formsocial mood, is not as harmless as it seems to be on the first sight. It can be even more noxious, if itis hidden under a verbal peel of conventional reasoning.

It is necessary to mention few more features of domestic chauvinism. It is insolent, unforgiving and often loud. These qualities of domestic chauvinism and the primitivism of their display have often greater social appeal than reasonable and judicious politics. When such dangerous social and psychological mechanisms persist, they can only be stopped by psychological measures or by other means which vagaries of the social mood would have difficulty overcoming. 
It can be said without any exaggeration, that domestic chauvinism is perilous to all without exception-small and large ethnic groups as well. The majority of the people understand or intuitively feel it, for it is often the main cause of national conflicts, bloodshed, "ethnic cleansing" and even genocide. That is why their fear of ethnic conflicts caused by the domestic chauvinism and vagaries of social mood is almost as strong as fear of economic problems and open violence. ${ }^{9}$ However, the problem would be only half as large if open daily dialogue and healthy common consciousness were allowed to limit its scope.

The scary fact is that domestic chauvinism is ingrained in state policy of many newly independent republics, espgcially when it comes to the local economic affairs. People have always been interested in their economic situation and the others. As long the comparisons on macro level were made by professionals and good journalists, counting who" got more" was not so dangerous. But when the problem of debts of other nations and other states received ethnic and national colouring, the comparisons between native people and other groups began. The latter were first called "migrants," or "uninvited visitors;" later they became "occupants."

Thus, a number of new states began organizing "ethnic cleansing." This policy was openly carried out in the Baltic republics, despite the fact that democratic reforms received powerful support form the majority of the local Russian population. Moreover, in a number of cases the Russian intellectuals supported claims to sovereignty. However, when their efforts and their merits were not only ignored, but also are used against them, the disappointment of many democratically oriented Russians was bitter.

But, even the Russian official policies employ domestic chauvinism. That, for example, is visible in the declarations of ultra nationalistic politicians such as Barkashov or Lisenko, who swing the bugaboo of broken Russian honour during the time of their election cam- paign of autumn 1995 and summer 1996. Unfortunately, many other political parties do not lag behind; trying to use, the most suitable and catchy ideas and slogans which have a strong nationalistic flavour.

Ethnic hostility did not arise suddenly. First, it ripened underground, thanks to the "merits" of the nationalimperious elite. What it can turn to and what threats it poses to Russia, can be deduced form the experience of Yugoslavia and the events in Dniestr republic, Abchazia, Karabach, Tadzhikistan, Chechnya.

The war in Chechnya, in its initial stage, seemed to serve a patriotic purpose. The central government of Russia set the objective to bring order and punish those who conceived the notion of Chechnya independence that led to the break-up of the integrity of Russia. Yet the means to achieve this objective were chosen incorrectly, as the struggle with the initiators of sovereignty of Chechnya expanded into a war against all of Chechnya's people. At the beginning of the war, the sociopolitical mood of the majority of Russians was supportive to the government policy of restoring order in Chechnya. However, when the people realized the essence of this war, they started to protest very sharply against its continuation. It is a pity the Russian government responded to their opinion with the enviable indifference. Russia will dearly pay for that, because, Chechnya might not be completely restored even in the 21st century.

Domestic chauvinism also becomes dangerous if it is fed by ill-conceived discussions often supported by the media about "which culture is older than which," and "which ethnic group contributed more to literature," and "who had what and who owned which territory, and when" etc. People, previously at peace with each other, suddenly begin to remember personal insults, look for comfort in some historical events, tally up ancient wars which occurred on their territory and project their meaning onto the present situation. The official propaganda of the many arising states consciously stirs such interests in order to heat up the emotions and awake unhealthy feelings of resentment and revenge, pushing the compatriots into dark business. Thus old wounds are opened again, and venom of hatred inflicts many sources of mass information.

Once domestic chauvinism is given a free ride, it promotes the rise of prejudice towards other ethnic groups in the name of ill-defined national interests. The end result is often an open display of hate leading to bloodshed, and long years of poisoned thinking, and deformed social mood.

\section{Social Mood and Potential for Conflict}

The analysis of the rise of ethnic selfconsciousness in the former USSR, with all its pluses and minuses shows clearly, thatit has high potential to create conflicts, and these conflicts in many respects determine the condition of the prevailing social mood. The study of the Centre of Sociology of interethnic relations in 1994 shows that, at present, in number of regions of the country, during ethnic conflicts, social status ofthe people of particular ethnic groups acquires a special meaning and affects the mutual relations between them. This is displayed in a number of cases:

1) In rather obvious functioning of negative national stereotypes in mass consciousness. When asked whether there is an ethnic group to which the respondents feel hostility, 11 percent of respondents in Bashkortostan, 27 percent in Moscow, and 24 percent in Kareliya gave an affirmative answer.

2) In a rather strong belief that the national belonging or ethnicity determines the economic and material situation of the people. Some respondents think that there are ethnic groups today that live financially better: 11 percent in Bashkortostan, 48 percent in Moscow, and 32 percent of Karelia. In the case of deterioration of a material situation some groups (especially Azeri, Armenians, the Jews) can become victims of these beliefs.

3) The support for infringement of ethnic interests is strong in the mass

Refuge, Vol. 17, No. 2 (April 1998) 
consciousness. Russian respondents frequently speak about it. 10 The conflict potential arising from

the deterioration of social mood is often exacerbated by the personnel selection made by the authorities of all levels, both central and local. Very often, the appointment to the office, good job, and acceptance to high school depends on person's ethnicity. Also the decision to introduce one language as the state language, i.e. language spoken by the local ethnic group, and ignoring the role of the Russian laI1guage, augments to the problem.

Thus, the social mood is influenced by the objective processes that take place in the political life in the former Soviet republics. These include: the disintegration of USSR, declaration of -independence of formerly allied republics, by creation of nation-state systems, by turning of a significant number of the Russian population into "second grade" citizens (this started with the passing of the law of the state language and not granting Russian any official status), with the inevitability of occurrence in the new states of Slavic movement and their links with the Russian national ( or nationalistic) movement in Russia itself.

The existence of these and otherproblems in the life of the people of postallied republics puts their social mood in a position of extreme instability and strong fluctuations. The results of sociological surveys, and also analysis of the literature and materials, published in press, transmitted by TV and the radio, enable the drawing of a conclusion, that the intensified social mood of the population during a transition period is subject to serious deformations.

There is another serious problem that has to be solved is that a certain part of citizens who previously had Soviet citizenship and certain rights, lost them after the collapse of the USSR, but did not regain them in the newly created states in which they found themselves. This is a legal and political, but not an ethnic problem. The rights of the individual, in opinion of the developers of the national doctrines in Russia, have an independent meaning and often do

Refuge, Vol. 17, No.2 (April 1998) not coincide with interests of the nation. ${ }^{11}$ It is quite possible to agree with the authors, offering to divide problems of citizenship, and interests of ethnicities and peoples. But two things have to be kept in mind: that the rights of the people determine the character of the international and ethnic relations, the internal policy and the whole political climate of the states; and that the "human face" of these processes is socialmood.

Taking into consideration all points of view, a legitimate way out of the given deadlock lies in the creation of a new union based on a commonly shared economic interests, cultural aspirations, legal values. This could be achieved by the unconditional removal of trade barriers, an establishment of a new economic and defensive union, and introduction of common citizenship.

The number of researchers believe, that in order to improve the interethnic relations, and to turn the social mood in the direction of positive emotions, it is not at all necessary to adhere to a one, uniform blueprint for peaceful settlement of various sorts of conflict. Most likely, during the search of ways for the formation of a positive social mood of the population it is necessary to be guided by the following principles:

- Principle of observance or restoration of peace between ethnicities and peoples, and resolving conflicts by only political and nonviolent methods;

- Principle of sequential democracy, including the observance of the rights of the individual, and the rights of ethnicities. These rights can be in conflict with each other. But that is what the art of political government should be all about-making acceptable decisions in each particular case;

- Principle of a flexible, individual approach to solving each problem in mutual relations between peoples, so that all sides can be satisfied;

- Principle of deep scientific expertise about regional wars and interethnic conflicts. In this,area, due to imperious structures of the political establishment, it was impossible to avoid impulsive politics that cost so

dearly,12

The analysis of s,?ciological information shows that in each republic the elements of ethnic separatism are displayed. And in these conditions, even if there will be positive changes in the economy and political sphere, the interethnic conflicts will not automatically disappear. They have their own logic, origin and development and can be characterized by rather heavy and steady inertia. Just as the historical memory of the peoples collects and keeps all the personal insults, the social mood of living generations is not capable of quickly overcoming feelings of ethnic hostility caused by the present unjustness. This is why the problems associated with realization and fulfilment of ethnic interests are capable of becoming-and in reality have become-the catalyst for alienation of people from each other.

\section{Conclusion}

The analysis of the degree of intensity of social mood allows to draw several conclusions.

Firstly, at each level of intensity both positive and negative features characterize the social mood. It displays itself not so much by the prevalence of some of them, but through their combination. This makes it hard to divide into clearly defined stages the ever-changing conditions and the content of social problems, as well as the fluctuation of a saturated social mood.

Secondly, the social mood-tension of both positive and negative character can accumulate secretly in the depths of public consciousness and can later develop into open forms of activity of the people.

Thirdly, any degree of intensity of the social mood in a reality can (and frequently it does) act in a deformed way, that is especially characteristic of societies in a transition period. In this case, the social mood has a great deal of suspicion, distortions and dislike of individuality.

Fourth, the social mood and degree of its intensity are hugely influenced by 
historical memory of the people. For example, the preservation of the ethos of Northern Caucasus in the historical consciousness, especially the Caucasus war in the XIX Century,13 as well as the memory of the huge shocks of the $\mathrm{XX}$ century (the civil war, Wodd WadI, the hardest years of reconstruction, and Stalin's reprisal in the 1930s and 1940s), playa significant role in the lives oflocal people. That explains the deep restraint of the people during economic and social conflicts.

!tis beyond any doubt, that the strong intensity of the social mood in the Russian society, in many respects determines, and in the foreseeable future will determine the character of interethnic relations as well as the degree of interethnic conflicts .••

\section{Notes}

1. U. V. Arutunian, and L. M. Drobizgeva, Russkie: etnosociologicheskie ocherki (Rus- sians: Ethnosociological Essays), (Moscow: Nauka, 1992).

2. V. 1. Merkushin, "Istoricheskoe soznanie, tendencii razvitiya $\mathrm{v}$ usloviyach perestroiki: rezul'tati sociologichskogo analiza" (Historical Consciousness: Tendency of Development in Conditions of Reorganization, Results of a Sociological Analysis), Informacionnij bullietin, no. 1 (10) (Moscow, 1991).

3. B. Giller, and B. Shatskich, "Opredelenie berega" (Definition of the Boundary), $A B V$, December 21, 1993.

4. See, brochure, Reformirovanie Rosii: mifi I real'nost' (Reforms of Russia: Myths and Reality), (Moscow: Nauka, 1994).

5. V. N., Ivanov, A. P. Kotov, 1. V. Ladodo, and M. M. Nazarov, "Etnopolitichskaya situaciya v regionachRossijskoj Federacii" (Ethnopolitical Situation in Regions of Russian Federation), SOCIS, no. 6 (Moscow, 1995).

6. See, brochure, Mezgnacional' nie otnosheniya $v$ regionach Rossii i SNG (Inter ethnic relations in regions of Russia and CIS), (Moscow: Nauka, 1994).
7. Giller, and Shatskich, "Opredelenie berega".

8. V. 1. Merkushin, "Istoricheskoe soznanie, tendencii rtazvitiya $\mathrm{v}$ usloviyach perestroiki: rezul'tati sociologichskogo analiza."

9. J. T. Tochenko, "Bitovoj shovinism" (Domestic Chauvinism), Sovremennoe Obchestvo, no. 1 (Moscow, 1994).

10. Ivanov, Kotov, Ladodo, and Nazarov, "Etnopolitichskaya situaciya v regionach Rossijskoj Federacii".

11. See, brochure Nacional' naya doktrina Rossii, problemi i prioriteti (National doctrine of Russia: Problem and Priorities), (Nayka: Moscow, 1994): 95.

12. T. Guzenkeva, "Nacional'naya politika . Rossii: utopii I real'nost"' (National Policy of Russia: Utopia and Reality) Svobodnaya mysl', no. 13 (Moscow, 1992): 89.

13. R. A. Chanachu, and O. M. Cvetkov, "Istoricheski fen omen $\mathrm{V}$ sovremennoj interpretacii," (A Historical Phenomenon in Modern Display), SOCIS, no. 11 (Moscow, 1995). o

\title{
So That Russia be "Saved" Anti-Jewish Violence in Russia: Its Roots and Consequences
}

\author{
By Tanya Basok and Alexander Benifand \\ Toronto: York Lanes Press, 1993 \\ ISBN 1-55014-010-8; 61pages; \$9.95
}

The growing popularity of ultra-nationalism and neo-Nazism in Europe and to some extent in North America is truly alarming, and this publication offers a perceptive analysis of the political trends in Russia and their implications for Russian Jews. It provides an historical analysis of anti-Jewish violence in Russia and poses an important question: can those conditions which resulted in anti-Jewish pogroms at the turn of the century reemerge today?

Dr. Basok and Dr. Benifand argue in this occasional paper that there is a number of clear indications of the popularity of the anti-Semitic and ultra-nationalist ideas not only among the masses and nationalist organizations but in the government as well.

Many of those who have been impoverished as a result of the "shock therapy" or who have grown extremely disillusioned with Yeltsin's reform policies, have become attracted to the solutions such as: getting rid of ethnic minorities, especially Jews, territorial expansion of the Russian federation to include the former Soviet republics, the extension of the Russian sphere of influence in Europe and Central Asia, protection of Russian lands (e.g., the Kurile Islands) and the curbing of ethnic nationalism within the Russian federation. Basok and Benifand's insightful analysis is an excellent attempt to understand the rise of ultra-nationalism in Russia.

\section{Available from:}

\section{Centre for Refugee Studies \\ Fax: (416) 736-5837 • Email: refuge@yorku.ca}

